\title{
Interferon-alpha-2a as a salvage treatment for hemorrhagic enteritis associated with Epstein-Barr Virus reactivation : a case report
}

\author{
D. Lankenau-Vela ${ }^{1,2}$, F. De la Garza-Salazar ${ }^{1,2}$, P. Colunga-Pedraza ${ }^{3}$, D. Jaime-Villalón ${ }^{4}$
}

(1) Universidad de Monterrey, Escuela de Medicina, Especialidades Medicas, Monterrey, Nuevo Leon, Mexico ; (2) Departamento de Medicina Interna, Hospital Christus Muguerza Alta Especialidad, Monterrey, Nuevo Leon, Mexico ; (3) Hematology Service, Hospital Universitario Dr. José Eleuterio González, Universidad Autónoma de Nuevo León, Monterrey, Mexico ; (4) Infectology Service, Hospital Christus Muguerza Alta Especialidad, Monterrey, Nuevo Leon, Mexico.

\begin{abstract}
Epstein-Barr virus [EBV] is a virus that infects almost all humans worldwide. After the acute phase of the infection, it stays in a latent form in B lymphocytes. EBV reactivation tends to occur in immunosuppressed patients. $E B V$ reactivation may involve the gastrointestinal tract; it has been associated mainly with colitis, but hemorrhagic enteritis has been poorly reported. Treatment usually includes antivirals. However, our patient did not respond to conventional treatment, so interferon alpha-2a was given as a salvage treatment. To our knowledge, this is the first reported case of hemorrhagic enteritis associated to $\mathrm{EBV}$ reactivation treated successfully with interferon alpha-2a. (Acta gastroenterol. belg., 2021, 84, 129-130).
\end{abstract}

Keywords : Epstein-barr virus reactivation, interferon, hemorrhagic enteritis, case report.

\section{Introduction}

Epstein-Barr virus [EBV] is a ubiquitous oncogenic virus that infects almost all humans during their lifetime (1). Following the acute phase, it infects B lymphocytes, persisting in a latent form. EBV reactivates -lytic phase- when cellular immunity weakens (2). Thus, EBV reactivation is commonly observed in immunosuppressed patients (3).

EBV reactivation affects the gastrointestinal tract, although enteritis associated with EBV reactivation has been poorly reported. Interferon-alpha may be used in EBV infection as it suppresses viral replication (4). In this case, interferon-alpha contributed to the resolution of massive lower gastrointestinal bleeding, which was refractory to other therapies. This is the first case of refractory hemorrhagic enteritis associated with EBV reactivation treated with interferon-alpha successfully.

\section{Case History}

A 51-year-old immunosuppressed man presented abdominal pain and fever after his chemotherapy session. He had a history of classic recurrent seminoma with extension to retroperitoneal nodes, which was treated with orchiectomy and five cycles of chemotherapy with bleomycin, etoposide, and cisplatin.

He was found to be tachycardic with a fever of $39^{\circ} \mathrm{C}$. Analysis of his blood revealed leukopenia of $350 / \mu \mathrm{L}$ (neutropenia of $20 / \mu \mathrm{L}$, lymphopenia of $310 / \mu \mathrm{L}$ ) and thrombocytopenia of $68,000 / \mu \mathrm{L}$. Neutropenic bacteremia

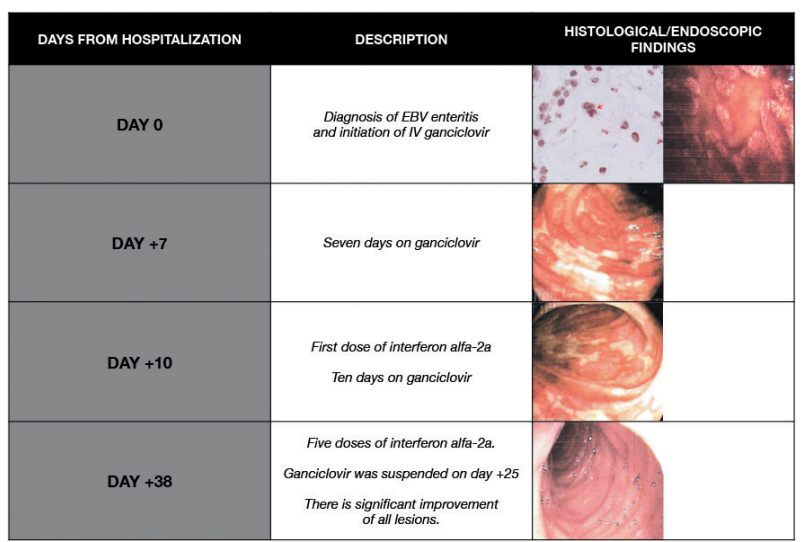

Figure 1. - Diagnosis of hemorrhagic enteritis associated with Epstein-Barr virus reactivation and efficacy of interferonalpha-2a. Abbreviations: EBV: Epstein-Barr virus. Note : immunohistochemistry was used to confirm the presence of EBV in gut cells.

due to E. coli was documented and treated with meropenem 2 gr i.v. every 8 hours showing an adequate response. Neutrophil count recovered to $2680 / \mu \mathrm{L}$ after seven days of treatment; he had a normal temperature of $36.5^{\circ} \mathrm{C}$.

During the next five days, he presented massive lower gastrointestinal bleeding. An upper endoscopy showed multiple aphthous-like linear ulcers interspersed with healthy tissue at the jejunum and ileum (Fig.1). Serologic tests revealed a positive serum EBV IgG and a viral load by quantitative real-time PCR showed 2895 copies/mL. Histopathology confirmed the presence of Epstein-Barr ; immunohistochemistry was positive to Epstein-Barr virus as well (Fig. 2). He was treated with ganciclovir 500mg i.v. every 12 hours, hemotherapy and vasopressors. Hemorrhage was refractory to medical treatment, so a jejunum resection and an ileostomy were performed successfully. However, he presented a first rebleeding episode on day 12 , which was also refractory to medical treatment and a second abdominal reintervention was performed.

Correspondence to : Fernando De la Garza Salazar, Dr. José Eleuterio González (Gonzalitos) S/N, Mitras Centro, 64460 Monterrey, N.L., México.

E-mail : fernandodelagarza@gmail.com

Submission date : 19/05/2020

Acceptance date : 25/06/2020 


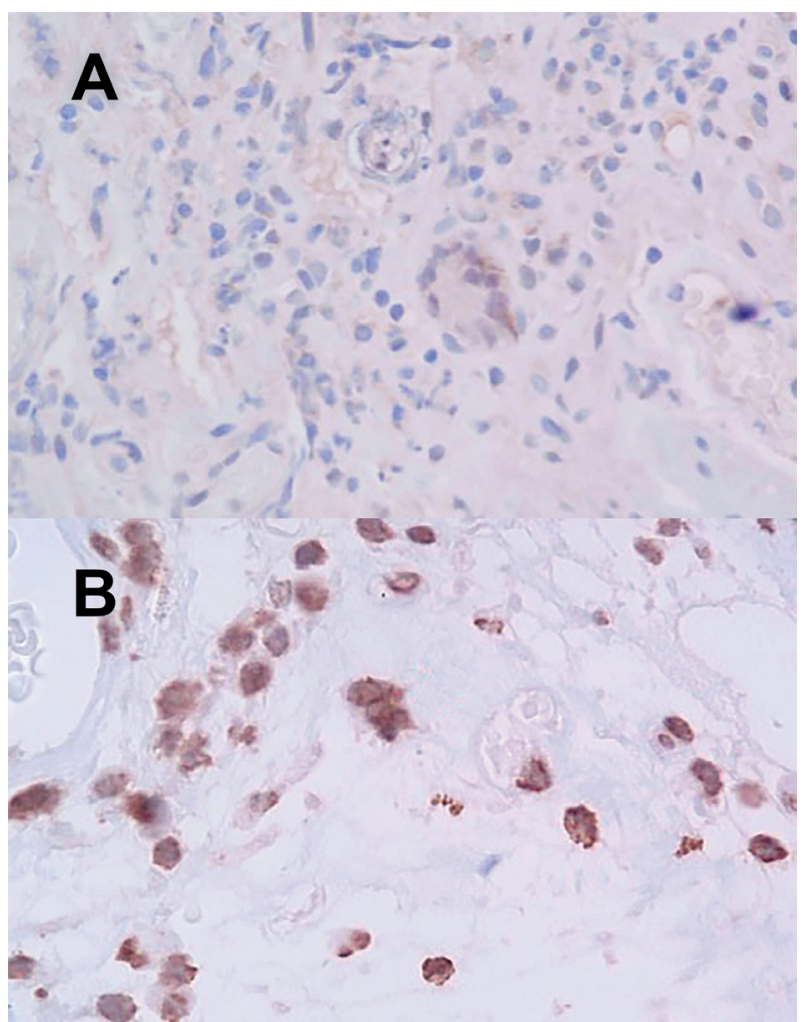

Figure 2. - Histopathological features of the disease Panel A, Hematoxylin \& eosin staining showing focal edema, vascular hyperplasia, interstitial hemorrhage, and diffuse lymphocytic infiltration, Panel B, positive immunohistochemistry for EBV.

However, he presented a second rebleeding episode. Treatment with pegylated interferon alpha-2a $180 \mu \mathrm{g}$ SQ (one dose weekly) was started as an experimental therapy (Fig.1). Finally, gastrointestinal bleeding subsided after two interferon alpha-2a doses, so ganciclovir was suspended after 25 days of administration. Three extra doses of interferon alpha-2a $180 \mu \mathrm{g}$ SQ weekly were given until complete clearance of EBV was evidenced by histopathology and endoscopy (Fig. 1). Finally, restoration of intestinal continuity was performed. The patient presented a favorable evolution and was discharged at 49 days of hospitalization. At one-year follow up he was in excellent clinical conditions.

\section{Discussion}

As to our knowledge, this is the first reported case of hemorrhagic enteritis associated with EBV reactivation ; but most importantly, the first one treated with interferon alpha-2a effectively.

EBV infects $\approx 90 \%$ of humans and -following the acute phase of infection- persists lifelong in a latent phase in B cells (5). EBV viral replication is promoted by immunodeficiency states (i.e. oncologic disorders). The switch from latency to the lytic cycle is known as EBV reactivation (3).

EBV infection is commonly located in inflammatory gastrointestinal lesions (i.e mucositis) (6). It is known that mucositis is a common side effect related to chemotherapy, thus explaining the presence of EBV in our patient (7). However, EBV reactivation involving the gastrointestinal tract is rare and poorly reported ; the first confirmed case of EBV-associated enteritis was reported in $2006(8,9)$.

It is known that IFN-alpha suppresses viral replication by inhibiting the basal transcription process (4). IFNalpha was previously shown to be effective in ChronicActive Epstein-Barr virus disease (CAEBV) and a recent case report presented a patient with interstitial pneumonia related to CAEBV that responded to inhaled IFN-alpha as well (10-12). For these previous facts, we used IFN-alpha-2a to treat this patient, and it showed to be efficient.

In conclusion, hemorrhagic enteritis associated with Epstein-Barr virus reactivation must be sought as a cause of gastrointestinal bleeding in immunosuppressed patients. Also, when presenting EBV systemic-related complications (such as enteritis) refractory to all available medical therapies, the administration of IFNalpha-2a should be considered.

\section{Conflict of interests}

None

\section{References}

1. BUSSCHAERT J., VAN DE BRUAENE C., VAN CAILLIE M., VAN HOOTEGEM P. A not-so-innocent kiss. Acta gastro-enterologica Belgica., 2019, 82(4) : 552.

2. KERR J.R. Epstein-Barr virus (EBV) reactivation and therapeutic inhibitors. J. Clin. Pathol., 2019 : jclinpath-2019-205822.

3. LI H., LIU S., HU J., LUO X., LI N., BODE A.M., et al. Epstein-Barr virus lytic reactivation regulation and its pathogenic role in carcinogenesis. Int. J. Biol. Sci., 2016, 12(11) : 1309.

4. CIRELLI R., TYRING S.K. Major therapeutic uses of interferons. Clin. Immunother, 1995, 3(1) : 27-87.

5. SARWARI N.M., KHOURY J.D., HERNANDEZ C.M.R. Chronic Epstein Barr virus infection leading to classical Hodgkin lymphoma. BMC hematology, 2016, 16(1) : 19.

6. RYAN J.L., SHEN Y.J., MORGAN D.R., THORNE L.B., KENNEY S.C., DOMINGUEZ R.L., et al. Epstein-Barr virus infection is common in inflamed gastrointestinal mucosa. Dig. Dis. Sci., 2012, 57(7) : 1887-98.

7. PICO J.L., AVILA-GARAVITO A., NACCACHE P. Mucositis: its occurrence, consequences, and treatment in the oncology setting. The oncologist, 1998, 3(6) : 446-51.

8. TASHIRO Y., GOTO M., TAKEMOTO Y., SATO E., SHIRAHAMA H., UTSUNOMIYA A., et al. Epstein-Barr virus-associated enteritis with multiple ulcers after stem cell transplantation : First histologically confirmed case. Pathol. Int., 2006, 56(9) : 530-7.

9. MATSUMOTO H., KIMURA Y., MURAO T., OSAWA M., AKIYAMA T., MANNOJI K., et al. Severe colitis associated with both epstein-barr virus and cytomegalovirus reactivation in a patient with severe aplastic anemia. Case Rep. Gastroenterol., 2014, 8(2) : 240-4.

10. TRIGG M., DE ALARCON P., RUMELHART S., HOLIDA M., GILLER R. Alpha-interferon therapy for lymphoproliferative disorders developing in two children following bone marrow transplants. J. Biol. Response Mod., 1989, 8(6) : 603.

11. SAKAI Y., OHGA S., TONEGAWA Y., TAKADA H., NAKAO F., NAKAYAMA H., et al. Interferon-alpha therapy for chronic active Epstein-Barr virus infection : potential effect on the development of T-lymphoproliferative disease. J. Pediatr. Hematol. Oncol., 1998, 20(4) : 342-6.

12. ROLIŃSKI J., GRYWALSKA E., PYZIK A., DZIK M., OPOKAWINIARSKA V., SURDACKA A., et al. Interferon alpha as antiviral therapy in chronic active Epstein-Barr virus disease with interstitial pneumonia-case report. BMC Infect. Dis., 2018, 18(1) : 190. 